\title{
Associations Between Post-migration Stressors and Psychiatric Disorders in Adult Refugees in European High Income Countries. A Systematic Review
}

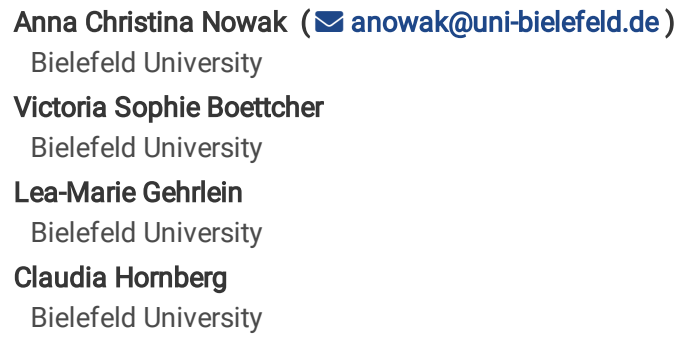

Research Article

Keywords: Post-migration Stressors, Adult Refugees, European High Income Countries, Legal Status, Social Support, Social Integration

Posted Date: September 15th, 2021

DOI: https://doi.org/10.21203/rs.3.rs-871673/v1

License: () (1) This work is licensed under a Creative Commons Attribution 4.0 International License. Read Full License 


\section{Abstract}

Background: Refugees and asylum seekers have a high prevalence of psychiatric disorders such as posttraumatic stress disorder (PTSD), anxiety and depression. Associations between the number of traumatic events and psychiatric disorders have been reported in literature, but knowledge on the influence of post-migration stressors on mental health outcomes in host countries remains scarce.

Method: Four databases in the field of public and mental health were systematically searched. From a total of 2,456 studies found, 1,777 were included for title and abstract screening and 61 full texts were separately screened for eligibility by 2 authors. Out of these studies, 23 studies were included in this systematic review. A narrative synthesis was undertaken.

Results: The overall findings showed that post-migration stressors have a significant impact on mental health outcomes. Especially uncertain legal status, missing social support and unemployment were shown to negatively influence mental health, but results vary among the different psychiatric disorders, i.e. post-traumatic stress disorder, depression and anxiety.

Discussion: Post-migration stressors can contribute to the high prevalence rates of psychiatric disorders in refugees in European high-income countries. However, results must be interpreted with caution because of the heterogeneous study populations included and the variety of post-migration stressors. None of the studies considered the effect of mental disorders on the perceived severity of post-migration stressors.

\section{Background}

To date, more than 80 million people have been forcibly displaced worldwide (1). From 2014 to 2017, nearly 4 million asylum seekers arrived in one of the member states of the European Union, with a peak in 2015 and 2016. As of 2017, the number of new arrivals has declined (2). Asylum seekers are persons who left their country and seek international protection, still awaiting a decision on their application for refugee status (3). Whereas, refugees are often defined according to the convention relating to the status of refugees or similar national recognition procedures as persons who are in fear of being persecuted and have crossed a national boarder (4).

Frequently, the terms are not well defined in the literature (5). For this review, it was decided to use the term "asylum seeker" for persons who are still awaiting a decision on their claim for asylum, whereas "refugees" are persons who are recognized by state authorities and have a legal entitlement.

Refugees and asylum seekers are highly burdened with psychiatric disorders because of traumatic experiences before, during and after their flight. Many studies have explored prevalence rates of posttraumatic stress disorder (PTSD), depression and anxiety as common mental disorders in refugee populations. According to the ICD-10 classification (6), PTSD is defined as a delayed mental reaction to a stressful threatening event. Depression is characterized by low mood, decreased energy and activity, whereas anxiety disorder is defined as a disorder that is evoked in well-defined, non-hazardous situations (6). Literature has estimated a prevalence of $4.4-86.0 \%$ for PTSD and $2.3-80 \%$ for depression, whereas, anxiety disorders had a higher estimated prevalence of $20.3-$ $88.0 \%$. Differences in the prevalence rates depend on study population, study quality, legal status, length of stay and differences in host countries (7).

Many studies show an association between traumatic events and mental illness. The likelihood of developing depression, PTSD or anxiety disorder significantly increases with the number of traumatic events experienced (7-10). However, clear results on the association between post-migration stressors and mental health outcomes are missing. Identifying and measuring post-migration stressors is difficult. To date, no standardized assessments are available. The Post-Migration Living Difficulties Checklist (38) is often used and adjusted to cultures, which makes it hard to compare different reception conditions.

It is also important to consider the situation of refugees and asylum seekers as a specific subpopulation. Many studies have examined people with a migration background, but they have not differentiated sufficiently between different types of migration (11).

Social determinants and related health inequalities are widely studied within and between populations (12). Health inequalities result from unequal distribution of power, money and resources which have an influence on socio-economic factors such as income, wealth, education, housing situation and access to health care (13). In particular, mental health is influenced by social inequalities in the social, economic and physical environment people live in (14). The social and political conditions in host countries can lead to material deprivation, uncertainty, social exclusion and discrimination in the refugee population, and can thus constitute a risk for traumatic experiences and worse mental health outcomes (15). A life course epidemiological perspective (16) can contribute to a better understanding of migrant health and the influence of stressors in different migration stages. Individual, environmental and contextual exposures in the new country of residence can influence refugees' and migrants' health directly as well as their descendants' health (16).

It was shown that ongoing stressors in the post-migration stage play a role for mental health trajectories. Stressors contributing to the development of psychiatric disorders include: language barriers $(7,9)$, missing social support in host countries $(17,18)$, socio-economic difficulties $(7,19)$ and the asylum procedure $(8,10)$. An uncertain legal status in particular can affect the integration of refugees and asylum seekers in host countries $(20,21)$.

In order to analyse the situation of refugees and asylum seekers in European countries and the potential post-migration stressors they are facing, a systematic review was conducted to answer the following question: What is the association between post-migration stressors on PTSD, anxiety and/or depression in adult refugees in European high income countries?

\section{Methods}

We conducted a systematic review according to the PRISMA Statement (22). No review protocol was published before. 
Four databases in the field of public health and psychology including PubMed, Psyclnfo, PSYNDEX and LIVIVO were searched by ACN for relevant literature in February 2019. The search was updated between October 31 and November 4, 2019. Different search terms regarding study population, mental health and post-migration stressors were combined. Different types of outcome and exposure search terms were used to get as broad an overview as possible (Table 1)

We included quantitative primary studies on refugees and asylum seekers aged 18 or older, which were conducted in European high income countries. Due to the lack of comparability of social conditions and asylum procedures in the host countries, studies conducted outside of Europe were excluded. The maximum length of stay in the destination country should not exceed ten years. Only studies with outcomes on depression, anxiety and PTSD were considered. Mental health outcomes had to be defined according to ICD-10, DSM IV or DSM V, and validated scales and checklists were used which allowed conclusions about the severity of mental health symptoms.

The measurement of post-migration living difficulties had to be described clearly. Studies were eligible if they were published in English or German from 1990 to 2019 .

Studies were excluded if internally displaced persons or minors were included in the study design. Intervention studies, study protocols, comments, qualitative studies and case studies also were excluded.

Titles and abstracts were screened for inclusion and exclusion criteria by two authors separately. ACN screened all articles, L-MG and VSB half of them. Eligible articles were then read in full by two authors each (ACN screened all articles, and LM und VSB half of them). Discrepancies were discussed among the three main authors.

Relevant data was extracted using a data extraction form developed by the main author (ACN). Data was structured by country of origin of the study population, country of study, mental health outcome, reported post-migration living difficulties and main results relevant to the current research question. Study results were clustered and compared in groups of post-migration living difficulties. A narrative synthesis was conducted. A meta-analysis was not done because of differences in the measurement of post-migration living difficulties and heterogeneity of study populations.

For critical appraisal of the studies, we used the Quality Assessment Tool for Observational Cohort and Cross-Sectional Studies from the National Heart, Lung and Blood Institute due to the cross-sectional or cohort design (23). The assessment was conducted by two authors. ACN assessed all the studies, VB und L-

MG half of them. Disagreements were resolved within the publication group to minimise the risk of bias across studies. Low-quality studies were not excluded to gain a broad view on different post-migration living difficulties on the mental health of refugees and asylum seekers, although their results were taken with caution.

\section{Results}

Study characteristics

Study selection is shown in Figure 1.

After analysis of full texts, 23 studies were included in the review. 21 studies had a cross-sectional design. Two studies with a longitudinal design were included $(24,25)$. Most studies were conducted in Switzerland $(n=5)$, followed by the Netherlands $(n=4)$, Norway $(n=3)$, UK $(n=3)$, Denmark $(n=2)$, Germany $(n=2)$ and Sweden $(n=2)$, while 2 studies $(26,27)$ had study sites in Germany, Italy and the UK. Table 2 presents the characteristics of the included studies.

In most studies, the Harvard Trauma Questionnaire (HTQ) and the Hopkins Symptoms Checklist (HSC) were used to assess PTSD, depression and anxiety. Apart from the HTQ and the HSC, three studies used the post-traumatic diagnostic scale (28-30), two studies used the composite international diagnostic interview $(31,32)$ or a structured clinical interview $(33,34)$. The Patient Health Questionnaire was used in two studies $(35,36)$. In one study $(37)$, the Survivor of Torture Assessment, the Present State Examination (PSE) and the DSM-III-R crieria for PTSD and depression were used. Mueller et al. (2017) used the ICD10 diagnosis, as this was a database study (29). In the studies of Priebe et al. (2013) and Bogić et al. (2012) the Mini International Neuropsychiatric Interview was used to assess mental disorders $(26,27)$.

The population included was not homogenous because of different migration backgrounds in the target countries, but most studies included persons from the Middle East and from African countries. Three studies included refugees from Eastern Europe $(26,27,33,34)$, and one included refugees and migrants from Turkey (29).

Sample sizes ranged from 854 participants in three different countries $(26,27)$ to 55 refugees in a Norwegian study $(34)$, with a mean of 276 participants per study.

A variety of post-migration stressors was investigated. Post-migration stressors were collected using mainly a culturally adapted version of the Post-Migration Living Difficulties Checklist (38). 11 studies reported specific results for legal status $(25,27,29-32,35,39-41)$, 9 for social support (24, 25, 32, 34, 34, 36, 37, $39,42), 6$ for unemployment $(24,25,32-34,43)$, and 3 for social integration $(27,28,34)$. Other factors such as cultural loss (17), perceived discrimination, homesickness and feelings of shame (29) were taken into account by only a few studies.

The methodological quality of studies varied. Most studies fulfilled the assessment criteria. 20 scored positive for 6-9 criteria, 3 met 4 or fewer criteria. All studies are shown below, but results must be taken with caution.

\section{Legal status and length of stay}


All studies reported a significant impact of an uncertain legal status on mental health outcomes, but results varied for PTSD, depression and anxiety. Asylum seekers with an uncertain residence status scored higher for PTSD, depression and anxiety $(30,31,35,39,44)$. In one study (40), an effect was found for depression and anxiety, but not for PTSD. By comparison, one German study, conducted in a clinical setting, found no difference in the prevalence of depressive disorders between migrants with a residence permit and asylum seekers. However, asylum seekers suffered from PTSD more often (29). After comparing two groups of Iraqi asylum seekers in the Netherlands, Laban et al. (2004) found a longer length of stay to be negatively associated with anxiety (OR 2.23, 95\% Cl: 1.15-4.08), depression (OR 1.84, 95\% Cl: 1.02-3.35) and the development of one or more psychiatric disorders (OR 1.27, 95\% Cl: 1.15-4.08) (31). Other studies found no significant association between length of stay and PTSD symptoms (41) or the total symptom score (44). Apart from the length of stay, asylum procedures have an influence on the development of one or more psychiatric disorders (32). A cohort study conducted in the Netherlands (25) which included 410 refugees at $\mathrm{t} 1$ and 172 at $\mathrm{t} 2$ (seven years later) reported a significant improvement of mental health outcomes after obtaining a residence permit. Changes in PTSD scores, depression and anxiety symptoms were mediated by changes in the living conditions, employment situation and social support.

\section{Social Support}

Social support is considered to be a key factor for mental-health well-being in refugees and asylum seekers $(24,25,32,33,36,37,39,42)$. In the late 1990 s, Gorst-Unsworth et al. (1998) found an association between high scores on the PSE Index, which was used for diagnosing PTSD and depression, and a low level of affective support $(p<0.01)$, separation from children $(p<0.01)$, lack of contact with political organisations in exile ( $<<0.01)$, low confidant support $(p<0.01)$ few social activities $(p<0.01)$ and the influence of racial attacks in exile on the diagnosis of depression (37).

As mentioned above, better mental health outcomes can possibly be explained by obtaining a residence permit, which means an improvement in social conditions and support (25). In another study, PTSD and depression were correlated with having a weak social network and poor social integration (33). In a longitudinal study on 139 tortured refugees at two different times, Carlsson et al. (2006) pointed out that social relationships were significantly associated with higher depression scores and PTSD (24). In a later study, on 63 refugees from an outpatient clinic, social relations were a predictor for anxiety, depression and PTSD (42). Laban et al. (2005) examined the relationship between family separation and suffering from one or more psychiatric disorders. Respondents who reported family issues had a higher chance to suffer from depression (OR 1.12, 95\% Cl: 1.01-3.15) and at least one psychiatric disorder (OR 1.12, 95\% Cl: 1.02-1.24) but not for anxiety (32). Gerritsen et al. (2006) reported similar results but showed a higher likelihood to develop mental health problems: Refugees and asylum seekers with less social support had a higher chance to suffer from PTSD (OR 3.51, 95\% Cl: 1.63-7.53) and depression and anxiety symptoms (OR $2.78,95 \% \mathrm{Cl} 1.36-5.65)(39)$. These results were partly supported by a Swiss cross-sectional study, where a regression model revealed a positive association between trauma and severity of PTSD, but lack of social support and post-migration stress were not associated with severity of PTSD (36).

\section{Social integration and employment}

Unemployment and poor or no social integration have an influence on different mental health outcomes. Laban et al. (2005) reported that refugees who were unemployed or worked below their qualification had a higher chance to suffer from one or more psychiatric disorders (OR 1.44, 95\% Cl: 1.15-1.81) or depression (OR 1.32, 95\% Cl: 1.08-1.61), but this pattern was not seen for anxiety (32). Carlsson et al. (2006) confirmed these results (24). They found an influence of unemployment on PTSD and depression scores, whereas Lavik et al. (1996) reported a significant association between unemployment and anxiety and/or depression ( $\mathrm{p}<0.02)(43)$. In a Norwegian study, the authors pointed out that unemployment even showed the strongest association with psychiatric morbidity and symptom severity compared to other post-migration stressors (33).

As a comparative study with migrants from the Balkans and refugees showed, employment was associated with a lower symptom level in both groups, and feeling integrated with less severe symptoms. Employment (OR $0.60,95 \% \mathrm{Cl}: 0.44-0.81$ ) and proficiency in the language of the host country (OR $0.69,95 \% \mathrm{Cl}$ : 0.52-0.92) seemed to act as protective factors for mental health (27). The effect can also be described vice versa. Mental health can be negatively associated with integration efforts. Schick et al. (2016) gave evidence that PTSD and depression influence social integration of refugees negatively (28).

\section{General results}

Some studies reported overarching findings on the influence of post-migration stressors by building an index on the mental health of refugees. All studies reported a significant influence of post-migration stressors on mental health outcomes, but prevalence of mental disorders differed between countries (26). Two Dutch studies showed associations of post-migration stress with psychopathology in general (32) as well as regarding various specific health outcomes, e.g. chronic conditions (39). In comparison, a Swedish study (45) showed that post-migration stressors were a significant predictor only for depression and PTSD, but not for anxiety.

Two studies from Switzerland conducted at the same outpatient clinics $(41,46)$ with 134 treatment-seeking refugees and asylum seekers mostly from Turkey, Iran and Sri Lanka reported a significant association of trauma exposure and post-migration living difficulties (PMLD) PTSD and depression. In one of the studies, PMLD were a significant predictor for PTSD (41).

\section{Discussion}

Our analysis of the available research studies shows that in general, a distinct association between post-migration stressors and deteriorated mental health outcomes in refugees and asylum seekers in European high income countries can be detected. A higher risk for developing mental illness was shown for legal status, social support, employment and social integration alike. It can therefore safely be assumed that post-migration stressors contribute to the high prevalence rates of psychiatric disorders in refugee and asylum seeker populations (26). However, any assumption of a causal relationship should be taken with caution. In all the studies reviewed, post-migration stressors were considered influencing factors for mental disorders while effects of mental disorders on 
the perceived severity of post-migration stressors were not shown. Moreover, it can be assumed that psychiatric disorders can act as a barrier to integration, as was shown by Schick et al. (2016) (28).

This review can confirm the results of a recently published meta-analysis by Hou et al. (2020) (47), that showed that post-migration stressors were associated negatively with mental health outcomes. Stressors regarding interpersonal interactions and combined subjective, interpersonal and material stressors were associated with anxiety, depression and PTSD, whereas subjective daily stressors were positively associated only with anxiety and PTSD. Furthermore, our synthesis highlights the importance of a secure legal status, possibilities for social integration and opportunities on the labour market in European high income countries for the mental well-being of asylum seekers and refugees.

In all studies, the legal status had an influence on mental health. However, the results vary among PTSD, depression and anxiety. Five studies (30, 31, 35, 39, 44) showed an effect of legal status on PTSD, depression and anxiety, but one (40) showed an effect on depression and anxiety, but not PTSD. One study reported no effects on depression and anxiety, but showed that asylum seekers suffer from PTSD more often than migrants with a resident permit (29). An improvement in mental health was seen after obtaining a residence permit. This could be explained by changing the living circumstances because a secure legal status facilitates active participation in the social environment in the host country (48). Interestingly, some studies reported an effect of the length of stay on mental health. It was hypothesized that a longer stay in the host country without a secure residence status leads to worse mental health, as the length of stay may encourage chronicity of psychiatric disorders. An Australian study (49) reported refugees with a longer period of resettlement were affected more strongly by psychological disorders, and a study from the USA (50) showed that refugees with a longer length of stay were likelier to suffer from psychiatric disorders.

Clear results were seen for social support. In all studies, social support had a significant influence on the development of a psychiatric disorder. This is also reported by a systematic review on clinical populations with mental disorders (51) and studies from outside the EU on refugees (18). Böge et al. (2020) (52) found a difference between types of social support and their effect on mental health in different host countries. Remarkably, Shelton et al. (2017) (53) highlighted the moderating role of cultural orientation on the association between perceived social support and mental health in a group of college students. Both the influence of types of social support in host countries and the moderating role of cultural differences should be considered by future studies to explore the association between social support and mental health in refugee populations more thoroughly. Furthermore, the reverse effect of mental health on perceived social support should be investigated more in more detail, as pointed out by Wang et al (2018) (51).

As was shown, social participation, particularly the employment situation, is associated with the development of a mental disorder. This seems to be independent of the legal status, as pointed out by Bogić et al. (2012) (26), who compared Balkan migrants from the Balkans and refugees. This effect was also seen in autochthonous populations, as in a sample from Germany (54). A review by Niemi et al. (2019) (48) highlighted the importance of social participation at different levels. Structural and social integration as well as community involvement by refugees and asylum seekers have a positive impact on their psychosocial well-being and can reduce psychosocial stress.

It should be pointed out that all results presented here must be taken with some caution. On the one hand, heterogeneous populations were included in most studies. On the other hand, post-migration stressors were not systematically recorded in some studies. This makes it difficult to compare results. Neither the survey of single factors nor the PMLD index can provide information on the perceived severity of post-migration stressors. Additionally, the situation in the host countries and the situation of different migrant population differs. This can lead to differences in prevalence rates (7).

\title{
Conclusions
}

This systematic review indicates that psychiatric disorders in adult refugees in European high income countries are influenced strongly by post-migration stressors such as an uncertain legal status, integration difficulties, lack of employment and missing social support. Our results must, however, be taken with some caution because of methodological difficulties. Furthermore, reverse effects of post-migration stressors on mental health were not investigated. We suggest that future studies should investigate the influence of psychiatric disorders on integration efforts of refugees in the host countries.

\section{Abbreviations}

\author{
BPRS - Brief Psychiatric-Rating-Scale \\ BSI - Brief Symptom Inventory \\ CAPS - Clinical Administered PTSD Scale \\ CIDI - Composite International Diagnostic Interview \\ DERS - Difficulties in Emotion Regulation Scale \\ DSM - Diagnostic and Statistical Manual of Mental Disorders \\ Duke-UNC FSSQ - Duke-UNC Functional Social Support Questionnaire \\ EU - European Union \\ GAD-7 - Generalized Anxiety Disorder Scale-7
}




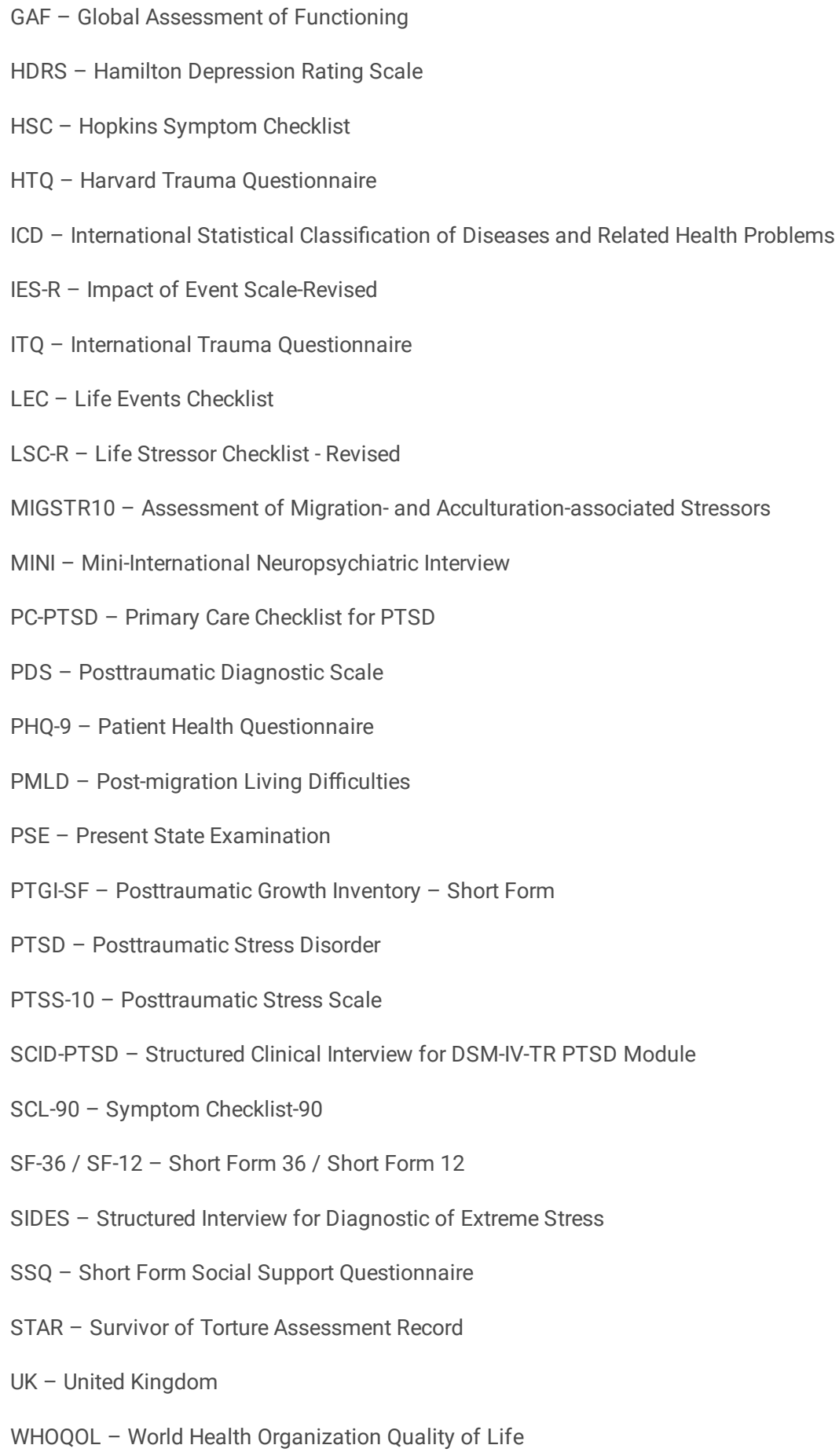

\section{Declarations}

Ethical approval and consent to participate not applicable

Consent for publication not applicable

Availability of data and materials All data generated or analysed during this study are included in this published article

Competing interests The authors declare that they have no competing interests.

Funding This work was supported by the Ministry for Culture and Science of the German State of North Rhine-Westphalia within the graduate school 'FlüGe Opportunities and challenges of global refugee migration for health care in Germany'.

Authors' contributions ACN and CH designed the systematic review. ACN, L-MM und VSB conducted the systematic review and the critical appraisal of the study. ACN prepared the manuscript. All authors contributed to the data interpretation and revised the manuscript. All authors approved the final version of the manuscript. 
Acknowledgements We thank Lira Ramadani for proofreading the manuscript and for her helpful comments.

\section{References}

1. UN High Commissioner for Refugees (UNHCR). Global Trends. Forced Displacement in 2020. 2021. https://www.unhcr.org/60b638e37/unhcr-globaltrends-2020. Accessed 31 Aug 2021

2. Eurostat. Asylbewerber und erstmalige Asylbewerber nach Staatsangehörigkeit, Alter und Geschlecht - jährliche aggregierte Daten (gerundet). Data File. 2021. https://appsso.eurostat.ec.europa.eu/nui/show.do?dataset=migr_asyappctza\&lang=de. Accessed 31 Aug 2021

3. UN High Commissioner for Refugees (UNHCR). UNHCR Master Glossary of Terms. 2006. https://www.refworld.org/docid/42ce7d444.html. Accessed 31 Aug 2021

4. UN General Assembly. Convention and Protocol relating to the Status or Refugees. 28 July 1951. United Nations, Treaty Series; 189:137.

5. Bradby H, Humphris R, Newall D et al. Public Health Aspects of Migrant Health. Copenhagen: WHO Regional Office for Europe 2015:46.

6. World Health Organization (WHO). ICD-10: international statistical classification of diseases and related health problems. Geneva: WHO; 2019

7. Bogic M, Njoku A, Priebe S. Long-term mental health of war-refugees: a systematic literature review. BMC Int Health Hum Rights. 2015;15:29.

8. Hocking DC, Kennedy GA, Sundram S. Mental disorders in asylum seekers: the role of the refugee determination process and employment. J Nerv Ment Dis. 2015;203:28-32.

9. Schweitzer RD, Brough M, Vromans L, Asic-Kobe M. Mental health of newly arrived Burmese refugees in Australia: contributions of pre-migration and postmigration experience. Aust N Z J Psychiatry. 2011;45:299-307.

10. Alpak G, Unal A, Bulbul F et al. Post-traumatic stress disorder among Syrian refugees in Turkey: a cross-sectional study. Int J Psychiatry Clin Pract. 2015;19:45-50.

11. Sangalang CC, Becerra D, Mitchell FM, Lechuga-Peña S, Lopez K, Kim I. Trauma, Post-Migration Stress, and Mental Health: A Comparative Analysis of Refugees and Immigrants in the United States. J Immigr Minor Health. 2019;21:909-919.

12. Marmot M. Social determinants of health inequalities. Lancet. 2005;365:1099-1104.

13. Braveman P, Gottlieb L. The social determinants of health: it's time to consider the causes of the causes. Public Health Rep. 2014;129 Suppl 2:19-31.

14. World Health Organization (WHO) and Calouste Gulbenkian Foundation. Social Determinants of Mental Health. Geneva: World Health Organization; 2014 https://apps.who.int/iris/bitstream/handle/10665/112828/9789241506809_eng.pdf. Accessed 31 Aug 2021

15. Hynie M. The Social Determinants of Refugee Mental Health in the Post-Migration Context: A Critical Review. Can J Psychiatry. 2018;63:297-303.

16. Spallek J, Zeeb H, Razum O. What do we have to know from migrants' past exposures to understand their health status? a life course approach. Emerg Themes Epidemiol. 2011;8:6.

17. Carswell K, Blackburn P, Barker C. The relationship between trauma, post-migration problems and the psychological well-being of refugees and asylum seekers. Int J Soc Psychiatry. 2011;57:107-119.

18. Schweitzer R, Melville F, Steel Z, Lacherez P. Trauma, post-migration living difficulties, and social support as predictors of psychological adjustment in resettled Sudanese refugees. Aust N Z J Psychiatry. 2006;40:179-187.

19. Gammouh OS, Al-Smadi AM, Tawalbeh LI, Khoury LS. Chronic diseases, lack of medications, and depression among Syrian refugees in Jordan, 20132014. Prev Chronic Dis. 2015;12:E10.

20. Momartin S, Steel Z, Coello M, Aroche J, Silove DM, Brooks R. A comparison of the mental health of refugees with temporary versus permanent protection visas. Med J Aust. 2006;185:357-361.

21. Steel Z, Silove D, Brooks R, Momartin S, Alzuhairi B, Susljik I. Impact of immigration detention and temporary protection on the mental health of refugees. Br J Psychiatry. 2006;188:58-64.

22. Page MJ, McKenzie JE, Bossuyt PM et al. The PRISMA 2020 statement: An updated guideline for reporting systematic reviews. PLoS Med. 2021;18:e1003583.

23. National Heart, Lung, and Blood Institute. Quality Assessment Tool for Observational Cohort and Cross-Sectional Studies. 2021. Available from: https://www.nhlbi.nih.gov/health-topics/study-quality-assessment-tools

24. Carlsson JM, Olsen DR, Mortensen EL, Kastrup M. Mental health and health-related quality of life: a 10-year follow-up of tortured refugees. J Nerv Ment Dis. 2006;194:725-731.

25. Lamkaddem M, Essink-Bot ML, Devillé W, Gerritsen A, Stronks K. Health changes of refugees from Afghanistan, Iran and Somalia: the role of residence status and experienced living difficulties in the resettlement process. Eur J Public Health. 2015;25:917-922.

26. Bogic M, Ajdukovic D, Bremner S et al. Factors associated with mental disorders in long-settled war refugees: refugees from the former Yugoslavia in Germany, Italy and the UK. Br J Psychiatry. 2012;200:216-223.

27. Priebe S, Jankovic Gavrilovic J, Bremner S et al. Psychological symptoms as long-term consequences of war experiences. Psychopathology. 2013;46:4554.

28. Schick M, Zumwald A, Knöpfli B et al. Challenging future, challenging past: the relationship of social integration and psychological impairment in traumatized refugees. Eur J Psychotraumatol. 2016;7:28057.

29. Müller MJ, Zink S, Koch E. The Negative Impact of an Uncertain Residence Status: Analysis of Migration-Related Stressors in Outpatients with Turkish Migration Background and Psychiatric Disorders in Germany Over a 10-Year Period (2005-2014). J Immigr Minor Health. 2018;20:317-326. 
30. Winkler JG, Brandl EJ, Bretz HJ, Heinz A, Schouler-Ocak M. [The Influence of Residence Status on Psychiatric Symptom Load of Asylum Seekers in Germany]. Psychiatr Prax. 2019;46:191-199.

31. Laban CJ, Gernaat HB, Komproe IH, Schreuders BA, De Jong JT. Impact of a long asylum procedure on the prevalence of psychiatric disorders in Iraqi asylum seekers in The Netherlands. J Nerv Ment Dis. 2004;192:843-851.

32. Laban CJ, Gernaat HB, Komproe IH, van der Tweel I, De Jong JT. Postmigration living problems and common psychiatric disorders in Iraqi asylum seekers in the Netherlands. J Nerv Ment Dis. 2005;193:825-832.

33. Teodorescu DS, Heir T, Hauff E, Wentzel-Larsen T, Lien L. Mental health problems and post-migration stress among multi-traumatized refugees attending outpatient clinics upon resettlement to Norway. Scand J Psychol. 2012;53:316-332.

34. Teodorescu DS, Siqveland J, Heir T, Hauff E, Wentzel-Larsen T, Lien L. Posttraumatic growth, depressive symptoms, posttraumatic stress symptoms, postmigration stressors and quality of life in multi-traumatized psychiatric outpatients with a refugee background in Norway. Health Qual Life Outcomes. 2012;10:84.

35. Leiler A, Bjärtå A, Ekdahl J, Wasteson E. Mental health and quality of life among asylum seekers and refugees living in refugee housing facilities in Sweden. Soc Psychiatry Psychiatr Epidemiol. 2019;54:543-551.

36. Hecker T, Huber S, Maier T, Maercker A. Differential Associations Among PTSD and Complex PTSD Symptoms and Traumatic Experiences and Postmigration Difficulties in a Culturally Diverse Refugee Sample. J Trauma Stress. 2018;31:795-804.

37. Gorst-Unsworth C, Goldenberg E. Psychological sequelae of torture and organised violence suffered by refugees from Iraq. Trauma-related factors compared with social factors in exile. Br J Psychiatry. 1998;172:90-94.

38. Silove D, Sinnerbrink I, Field A, Manicavasagar V, Steel Z. Anxiety, depression and PTSD in asylum-seekers: Assocations with pre-migration trauma and post-migration stressors. British Journal of Psychiatry. 1997;170:351-357.

39. Gerritsen AA, Bramsen I, Devillé W, van Willigen LH, Hovens JE, van der Ploeg HM. Physical and mental health of Afghan, Iranian and Somali asylum seekers and refugees living in the Netherlands. Soc Psychiatry Psychiatr Epidemiol. 2006;41:18-26.

40. Morgan G, Melluish S, Welham A. Exploring the relationship between postmigratory stressors and mental health for asylum seekers and refused asylum seekers in the UK. Transcult Psychiatry. 2017;54:653-674.

41. Spiller TR, Schick M, Schnyder U, Bryant RA, Nickerson A, Morina N. Somatisation and anger are associated with symptom severity of posttraumatic stress disorder in severely traumatised refugees and asylum seekers. Swiss Med Wkly. 2016;146:w14311.

42. Carlsson JM, Mortensen EL, Kastrup M. Predictors of mental health and quality of life in male tortured refugees. Nord J Psychiatry. 2006;60:51-57.

43. Lavik NJ, Hauff E, Skrondal A, Solberg O. Mental disorder among refugees and the impact of persecution and exile: some findings from an out-patient population. Br J Psychiatry. 1996;169:726-732.

44. Heeren M, Wittmann L, Ehlert U, Schnyder U, Maier T, Müller J. Psychopathology and resident status - comparing asylum seekers, refugees, illegal migrants, labor migrants, and residents. Compr Psychiatry. 2014;55:818-825.

45. Steel JL, Dunlavy AC, Harding CE, Theorell T. The Psychological Consequences of Pre-Emigration Trauma and Post-Migration Stress in Refugees and Immigrants from Africa. J Immigr Minor Health. 2017;19:523-532.

46. Nickerson A, Bryant RA, Schnyder U, Schick M, Mueller J, Morina N. Emotion dysregulation mediates the relationship between trauma exposure, postmigration living difficulties and psychological outcomes in traumatized refugees. J Affect Disord. 2015;173:185-192.

47. Hou WK, Liu H, Liang L et al. Everyday life experiences and mental health among conflict-affected forced migrants: A meta-analysis. J Affect Disord. 2020;264:50-68.

48. Niemi M, Manhica H, Gunnarsson D, Ståhle G, Larsson S, Saboonchi F. A Scoping Review and Conceptual Model of Social Participation and Mental Health among Refugees and Asylum Seekers. International Journal of Environmental Research and Public Health. 2019;16:4027.

49. Uribe Guajardo MG, Slewa-Younan S, Smith M, Eagar S, Stone G. Psychological distress is influenced by length of stay in resettled Iraqi refugees in Australia. Int J Ment Health Syst. 2016;10:4.

50. Mulugeta W, Xue H, Glick M, Min J, Noe MF, Wang Y. Burden of Mental Illness and Non-communicable Diseases and Risk Factors for Mental Illness Among Refugees in Buffalo, NY, 2004-2014. J Racial Ethn Health Disparities. 2019;6:56-63.

51. Wang J, Mann F, Lloyd-Evans B, Ma R, Johnson S. Associations between loneliness and perceived social support and outcomes of mental health problems: a systematic review. BMC Psychiatry. 2018;18:156.

52. Böge K, Karnouk C, Hahn E, Demir Z, Bajbouj M. On Perceived Stress and Social Support: Depressive, Anxiety and Trauma-Related Symptoms in ArabicSpeaking Refugees in Jordan and Germany. Front Public Health. 2020;8:239.

53. Shelton AJ, Wang CDC, Zhu W. Perceived Social Support and Mental Health: Cultural Orientations as Moderators. Journal of College Counseling. 2017;20:194-207.

54. Neubert M, Süssenbach P, Rief W, Euteneuer F. Unemployment and mental health in the German population: the role of subjective social status. Psychol Res Behav Manag. 2019;12:557-564.

\section{Tables}

Table 1: Search terms 


\begin{tabular}{|ll|}
\hline Study population & Refugee* OR asylum seeker* \\
\hline Outcome measures & Psychological disorder \\
& Mental disorder \\
& Mental health \\
& Depress* \\
& Trauma \\
\hline Exposure measures & Stressor \\
& Living situation \\
& Social condition \\
& Legal status \\
& Accommodation \\
\hline
\end{tabular}

Table 2: Characteristics of the included studies 


\begin{tabular}{|c|c|c|c|c|c|c|c|c|}
\hline $\begin{array}{l}\text { Author and } \\
\text { year }\end{array}$ & $\begin{array}{l}\text { Study. } \\
\text { Design }\end{array}$ & Sample & $\begin{array}{l}\text { Country of } \\
\text { Origin }\end{array}$ & $\begin{array}{l}\text { Country of } \\
\text { Study. }\end{array}$ & $\begin{array}{l}\text { Health } \\
\underline{\text { determinants }}\end{array}$ & $\underline{\text { PMLD }}$ & $\begin{array}{l}\text { Outcomes of } \\
\underline{\text { Interest }}\end{array}$ & $\underline{\text { Results }}$ \\
\hline $\begin{array}{l}\text { Bogic et al., } \\
2012\end{array}$ & $\begin{array}{l}\text { Multicenter } \\
\text { survey }\end{array}$ & $\begin{array}{l}\mathrm{N}=854 \\
\text { participants } \\
\text { ( } \mathrm{n}=255 \text { in } \\
\text { Germany, } \mathrm{n}=297 \\
\text { in Italy and } \\
\mathrm{n}=302 \text { in UK) } \\
\text { aged between } 18 \\
\text { and } 65 \text { years } \\
\text { who experienced } \\
\text { at least one } \\
\text { traumatic war- } \\
\text { related event }\end{array}$ & $\begin{array}{l}\text { Former } \\
\text { Yugoslavian } \\
\text { countries }\end{array}$ & $\begin{array}{l}\text { Germany, } \\
\text { Italy, UK }\end{array}$ & $\begin{array}{l}\text { Mental } \\
\text { disorders }\end{array}$ & $\begin{array}{l}\text { Traumatic } \\
\text { experience } \\
\text { before, during } \\
\text { and after war; } \\
\text { education, } \\
\text { employment, } \\
\text { residence status, } \\
\text { separation from } \\
\text { family, } \\
\text { difficulties } \\
\text { obtaining a work } \\
\text { permit, financial } \\
\text { difficulties, } \\
\text { inadequate } \\
\text { accommodation, } \\
\text { difficulties } \\
\text { assessing } \\
\text { medical care }\end{array}$ & $\begin{array}{l}\text { LSC-R, } \\
\text { Structured } \\
\text { Interview } \\
\text { about } \\
\text { possible post- } \\
\text { migration } \\
\text { stressors, } \\
\text { MINI }\end{array}$ & $\begin{array}{l}\text { Mood disorders } \\
\text { and anxiety } \\
\text { disorders were } \\
\text { associated with } \\
\text { post-migration } \\
\text { stressors. } \\
\text { Prevalence } \\
\text { differs between } \\
\text { countries }\end{array}$ \\
\hline $\begin{array}{l}\text { Carlsson et } \\
\text { al., 2006a }\end{array}$ & $\begin{array}{l}\text { Longitudinal } \\
\text { Study }\end{array}$ & $\begin{array}{l}\mathrm{N}=139 \\
\text { participants who } \\
\text { were exposed to } \\
\text { torture }\end{array}$ & $\begin{array}{l}\text { Iran, Iraq, } \\
\text { Lebanon }\end{array}$ & Denmark & $\begin{array}{l}\text { PTSD, } \\
\text { Anxiety, } \\
\text { Depression }\end{array}$ & $\begin{array}{l}\text { Torture, family } \\
\text { separation, } \\
\text { mental and } \\
\text { physical } \\
\text { complaints }\end{array}$ & HTQ, HSCL & $\begin{array}{l}\text { High emotional } \\
\text { distress at follov } \\
\text { up; social } \\
\text { relations and } \\
\text { unemployment } \\
\text { were predictors } \\
\text { for mental healtl } \\
\text { symptoms }\end{array}$ \\
\hline $\begin{array}{l}\text { Carlsson et } \\
\text { al., 2006b }\end{array}$ & $\begin{array}{l}\text { Cross- } \\
\text { sectional } \\
\text { study }\end{array}$ & $\begin{array}{l}\mathrm{N}=63 \text { male } \\
\text { tortured refugees }\end{array}$ & $\begin{array}{l}\text { Iraq, } \\
\text { Afghanistan, } \\
\text { Iran }\end{array}$ & Denmark & $\begin{array}{l}\text { PTSD, } \\
\text { Anxiety, } \\
\text { Depression, } \\
\text { Health } \\
\text { related } \\
\text { quality of life }\end{array}$ & $\begin{array}{l}\text { Language } \\
\text { ability, } \\
\text { Citizenship, } \\
\text { Income, } \\
\text { Employment, } \\
\text { Income / } \\
\text { Financial } \\
\text { security, , Social } \\
\text { network, } \\
\text { Belonging to } \\
\text { Denmark, } \\
\text { Discrimination, } \\
\text { Religious } \\
\text { practice }\end{array}$ & $\begin{array}{l}\text { HTQ, HSCL } \\
\text { HDRS, } \\
\text { WHOQOL }\end{array}$ & $\begin{array}{l}\text { Social relations } \\
\text { are an important } \\
\text { predictor for } \\
\text { Depression }\end{array}$ \\
\hline $\begin{array}{l}\text { Carswell et } \\
\text { al., } 2011\end{array}$ & $\begin{array}{l}\text { Cross- } \\
\text { sectional } \\
\text { study }\end{array}$ & $\begin{array}{l}\mathrm{N}=47 \text { Refugees } \\
\text { and Asylum } \\
\text { Seekers }\end{array}$ & $\begin{array}{l}\text { Middle East, } \\
\text { Africa, } \\
\text { Europe, Asia, } \\
\text { South } \\
\text { America }\end{array}$ & UK & $\begin{array}{l}\text { PTSD, } \\
\text { Depression, } \\
\text { Anxiety }\end{array}$ & $\begin{array}{l}\text { Asylum status, } \\
\text { experience of } \\
\text { detention, } \\
\text { language ability, } \\
\text { post-migration } \\
\text { and asylum } \\
\text { related } \\
\text { problems, Social } \\
\text { Support }\end{array}$ & $\begin{array}{l}\text { HTQ, HSCL } \\
\text { The } \\
\text { Demographic } \\
\text { and Post- } \\
\text { Migration } \\
\text { Living } \\
\text { Difficulty } \\
\text { Questionnaire, } \\
\text { SSQ6, Duke- } \\
\text { UNC FSSQ }\end{array}$ & $\begin{array}{l}\text { PTSD symptom: } \\
\text { were associated } \\
\text { with adaptation } \\
\text { difficulties, loss } \\
\text { of culture and } \\
\text { support, } \\
\text { emotional } \\
\text { distress were } \\
\text { associated with } \\
\text { loss of culture } \\
\text { and support; } \\
\text { post-migration } \\
\text { stressors explair } \\
\text { the variance in } \\
\text { PTSD symptom: }\end{array}$ \\
\hline $\begin{array}{l}\text { Gerritsen et } \\
\text { al., } 2006\end{array}$ & $\begin{array}{l}\text { Cross- } \\
\text { Sectional } \\
\text { Study }\end{array}$ & $\begin{array}{l}\mathrm{n}=178 \text { Refugees } \\
\text { from three } \\
\text { municipalities; } \\
\mathrm{n}=232 \text { asylum } \\
\text { seekers from } \\
\text { reception centers }\end{array}$ & $\begin{array}{l}\text { Afghanistan, } \\
\text { Iran, } \\
\text { Somalia }\end{array}$ & Netherlands & $\begin{array}{l}\text { General } \\
\text { health, PTSD, } \\
\text { Depression, } \\
\text { Anxiety }\end{array}$ & $\begin{array}{l}\text { Residence } \\
\text { permit, social } \\
\text { network \& social } \\
\text { support, period } \\
\text { of residence, } \\
\text { acculturation }\end{array}$ & $\begin{array}{l}\text { SF36, HTQ, } \\
\text { HSCL }\end{array}$ & $\begin{array}{l}\text { Legal status has } \\
\text { an impact on } \\
\text { PTSD and } \\
\text { Depression / } \\
\text { Anxiety, more } \\
\text { post-migration } \\
\text { stress and less } \\
\text { social support } \\
\text { were associated } \\
\text { with PTSD and } \\
\text { Depression }\end{array}$ \\
\hline $\begin{array}{l}\text { Gorst- } \\
\text { Unsworth \& } \\
\text { Goldenberg, } \\
1998\end{array}$ & $\begin{array}{l}\text { Cross- } \\
\text { Sectional } \\
\text { Study }\end{array}$ & $\begin{array}{l}\mathrm{N}=84 \text { male Iraqi } \\
\text { refugees between } \\
18 \text { and } 59 \text { years } \\
\text { old }\end{array}$ & Iraq & UK & $\begin{array}{l}\text { PTSD, } \\
\text { Depression }\end{array}$ & Social Support & $\begin{array}{l}\text { HTQ, STAR, } \\
\text { Rand Social } \\
\text { Activities } \\
\text { Questionnaire, } \\
\text { Duke-UNC } \\
\text { FSSQ, PSE }\end{array}$ & $\begin{array}{l}\text { Social support is } \\
\text { associated with } \\
\text { PTSD and } \\
\text { depressive } \\
\text { symptoms }\end{array}$ \\
\hline $\begin{array}{l}\text { Hecker et al, } \\
2018\end{array}$ & $\begin{array}{l}\text { Cross- } \\
\text { sectional } \\
\text { study }\end{array}$ & $\mathrm{N}=94$ refugees & $\begin{array}{l}\text { Majority } \\
\text { from Syria, } \\
\text { Afghanistan, } \\
\text { Eritrea }\end{array}$ & Switzerland & $\begin{array}{l}\text { PTSD, } \\
\text { complex } \\
\text { PTSD, } \\
\text { disturbances } \\
\text { in self- } \\
\text { organisation }\end{array}$ & $\begin{array}{l}\text { PMLD Checklist, } \\
\text { Social Provision } \\
\text { Scale }\end{array}$ & $\begin{array}{l}\text { HTQ, ITQ, ICD- } \\
11 \text { PTSD, ICD- } \\
11 \text { CPTSD, } \\
\text { PHQ-9, Social } \\
\text { Provision } \\
\text { Scale }\end{array}$ & $\begin{array}{l}\text { Refugees } \\
\text { experience in } \\
\text { average } 6,44 \\
\text { PMLD, lack of } \\
\text { social support } \\
\text { and PMLD were } \\
\text { significant } \\
\text { correlated with }\end{array}$ \\
\hline
\end{tabular}




\begin{tabular}{|c|c|c|c|c|c|c|c|c|}
\hline & & & & & & & & $\begin{array}{l}\text { DSO symptom } \\
\text { severity but not } \\
\text { with PTSD } \\
\text { symptom severit }\end{array}$ \\
\hline $\begin{array}{l}\text { Heeren et } \\
\text { al., } 2014\end{array}$ & $\begin{array}{l}\text { Cross- } \\
\text { sectional } \\
\text { study }\end{array}$ & $\begin{array}{l}\mathrm{N}=65 \text { asylum } \\
\text { seekers, } \mathrm{n}=34 \\
\text { refugees, } \mathrm{n}=21 \\
\text { illegal migrants } \\
\mathrm{n}=26 \text { labor } \\
\text { migrants, } \mathrm{n}=56 \\
\text { residents }\end{array}$ & & Switzerland & $\begin{array}{l}\text { PTSD, } \\
\text { Depression, } \\
\text { Anxiety }\end{array}$ & $\begin{array}{l}\text { Structural, } \\
\text { cultural, } \\
\text { interactive and } \\
\text { identificational } \\
\text { integration (work } \\
\text { satisfaction, } \\
\text { social contacts } \\
\text { outside the } \\
\text { family, social } \\
\text { contacts with } \\
\text { residents, leisure } \\
\text { activities, news } \\
\text { consumption, } \\
\text { German } \\
\text { proficiency) }\end{array}$ & $\begin{array}{l}\text { HTQ, HSCL, } \\
\text { PDS }\end{array}$ & $\begin{array}{l}\text { High rates of } \\
\text { depression and } \\
\text { PTSD in asylum } \\
\text { seekers, illegal } \\
\text { migrants and } \\
\text { refugees; Asylun } \\
\text { seekers had the } \\
\text { highest rates of } \\
\text { anxiety; resident } \\
\text { status was } \\
\text { associated with } \\
\text { mental health, } \\
\text { especially for } \\
\text { PTSD for asylun } \\
\text { seekers and } \\
\text { refuges as well } \\
\text { as depression } \\
\text { and anxiety for } \\
\text { illegal migrants, } \\
\text { asylum seekers } \\
\text { and refugees }\end{array}$ \\
\hline $\begin{array}{l}\text { Laban et al., } \\
2004\end{array}$ & $\begin{array}{l}\text { Cross- } \\
\text { sectional } \\
\text { study }\end{array}$ & $\begin{array}{l}\mathrm{N}=294,(\mathrm{n}=146 \\
\text { residence less } \\
\text { than } 6 \text { months, } \\
\mathrm{n}=151 \text { more than } \\
2 \text { years) }\end{array}$ & Iraq & Netherlands & PTSD & $\begin{array}{l}\text { Length of stay in } \\
\text { the Netherlands }\end{array}$ & HTQ, CIDI & $\begin{array}{l}\text { Levels of } \\
\text { psychiatric } \\
\text { disorders are } \\
\text { much higher in } \\
\text { the group that } \\
\text { was in the } \\
\text { asylum procedu } \\
\text { for more than 2 } \\
\text { years? overall } \\
\text { risk for higher } \\
\text { pathology }\end{array}$ \\
\hline $\begin{array}{l}\text { Laban et al., } \\
2005\end{array}$ & $\begin{array}{l}\text { Cross- } \\
\text { sectional } \\
\text { study }\end{array}$ & $\begin{array}{l}\mathrm{N}=294,(\mathrm{n}=146 \\
\text { residence less } \\
\text { than } 6 \text { months, } \\
\mathrm{n}=151 \text { more than } \\
2 \text { years) }\end{array}$ & Iraq & Netherlands & PTSD & $\begin{array}{l}\text { PMLD Checklist; } \\
\text { Family issues, } \\
\text { discrimination, } \\
\text { asylum } \\
\text { procedure, } \\
\text { socioeconomic } \\
\text { living conditions, } \\
\text { socioreligious } \\
\text { aspects, } \\
\text { employment }\end{array}$ & HTQ, CIDI & $\begin{array}{l}\text { Significant } \\
\text { relationship } \\
\text { between } \\
\text { postmigration } \\
\text { living difficulties } \\
\text { and } \\
\text { psychopatholog } \\
\text { unemployment, } \\
\text { stress in family } \\
\text { and stress in the } \\
\text { asylum procedu } \\
\text { have the highest } \\
\text { odds for } \\
\text { psychopatholog }\end{array}$ \\
\hline $\begin{array}{l}\text { Lamkaddem } \\
\text { et al., } 2015\end{array}$ & $\begin{array}{l}\text { Cohort } \\
\text { study }\end{array}$ & $\begin{array}{l}\mathrm{N}=172 \text { ( } \mathrm{n}=68 \\
\text { newly arrived, } \\
\mathrm{n}=104 \\
\text { longstanding) }\end{array}$ & $\begin{array}{l}\text { Afghanistan, } \\
\text { Iran \& } \\
\text { Somalia }\end{array}$ & Netherlands & $\begin{array}{l}\text { PTSD, } \\
\text { General } \\
\text { Health, } \\
\text { Anxiety, } \\
\text { Depression }\end{array}$ & $\begin{array}{l}\text { Asylum } \\
\text { Procedure, New } \\
\text { Culture / } \\
\text { Language, } \\
\text { Housing, Work, } \\
\text { Family / Social } \\
\text { Support, Social } \\
\text { Position, } \\
\text { Missing country } \\
\text { of origin }\end{array}$ & $\begin{array}{l}\text { SF-36, HTQ, } \\
\text { HSCL }\end{array}$ & $\begin{array}{l}\text { Improvement of } \\
\text { mental and } \\
\text { general health } \\
\text { after obtaining a } \\
\text { residence permit } \\
\text { improvements } \\
\text { were related to } \\
\text { living conditions } \\
\text { employment anc } \\
\text { the presence of } \\
\text { social support; } \\
\text { the change in } \\
\text { legal status has } \\
\text { mediating effect } \\
\text { on mental healtt }\end{array}$ \\
\hline $\begin{array}{l}\text { Lavik et al., } \\
1996\end{array}$ & $\begin{array}{l}\text { Cross } \\
\text { sectional } \\
\text { study }\end{array}$ & $\begin{array}{l}\mathrm{N}=231 \text { refugee } \\
\text { patients }\end{array}$ & $\begin{array}{l}\text { Afrika (12\%), } \\
\text { Far East } \\
\text { (19\%), } \\
\text { Middle East } \\
\text { (52\%), Latin } \\
\text { America } \\
(8 \%), \text { Europe } \\
(9 \%)\end{array}$ & Norway & $\begin{array}{l}\text { PTSD, } \\
\text { Depression, } \\
\text { Anxiety }\end{array}$ & $\begin{array}{l}\text { Legal status, } \\
\text { Employment / } \\
\text { Education, } \\
\text { Family situation }\end{array}$ & $\begin{array}{l}\text { Free } \\
\text { Psychiatric } \\
\text { Interviews, } \\
\text { BPRS, HSCL, } \\
\text { PTSS-10, GAF }\end{array}$ & $\begin{array}{l}\text { Unemployment } \\
\text { and inactivity ar } \\
\text { a predictor for } \\
\text { missing } \\
\text { psychosocial } \\
\text { functioning and } \\
\text { depression and } \\
\text { anxiety in exile }\end{array}$ \\
\hline $\begin{array}{l}\text { Leiler et al., } \\
2018\end{array}$ & $\begin{array}{l}\text { Cross- } \\
\text { sectional } \\
\text { study }\end{array}$ & $\begin{array}{l}\mathrm{N}=367 \text { asylum } \\
\text { seekers and } \\
\mathrm{N}=143 \text { refugees } \\
\text { with residence } \\
\text { permit but with } \\
\text { unclear housing } \\
\text { situation; both } \\
\text { groups living in } \\
\text { refugee housing } \\
\text { facilities }\end{array}$ & $\begin{array}{l}\text { Afghanistan, } \\
\text { Syria, Iraq, } \\
\text { Iran, Eritrea, } \\
\text { Somalia }\end{array}$ & Sweden & $\begin{array}{l}\text { PTSD, } \\
\text { Depression, } \\
\text { Anxiety }\end{array}$ & $\begin{array}{l}\text { Housing facility, } \\
\text { residence status }\end{array}$ & $\begin{array}{l}\text { PHQ-9, GAD-7, } \\
\text { PC-PTSD, } \\
\text { WHOQOL }\end{array}$ & $\begin{array}{l}\text { More asylum } \\
\text { seekers showed } \\
\text { clinically } \\
\text { significant } \\
\text { symptoms of } \\
\text { PTSD and in } \\
\text { anxiety scores }\end{array}$ \\
\hline
\end{tabular}




\begin{tabular}{|c|c|c|c|c|c|c|c|c|}
\hline $\begin{array}{l}\text { Morgan et } \\
\text { al., } 2017\end{array}$ & $\begin{array}{l}\text { Cross- } \\
\text { Sectional } \\
\text { Study }\end{array}$ & $\begin{array}{l}\mathrm{N}=97 \text { asylum } \\
\text { seekers or } \\
\text { refused asylum } \\
\text { seekers }\end{array}$ & 25 countries & UK & $\begin{array}{l}\text { PTSD, } \\
\text { Distress, } \\
\text { Anxiety, } \\
\text { Depression }\end{array}$ & $\begin{array}{l}\text { Social support, } \\
\text { length of stay, } \\
\text { PMLD Checklist }\end{array}$ & $\begin{array}{l}\text { Traumatic } \\
\text { Exposure } \\
\text { Questionnaire } \\
\text { (part of HTQ), } \\
\text { HSCL }\end{array}$ & $\begin{array}{l}\text { Refused asylum } \\
\text { seekers report } \\
\text { higher anxiety } \\
\text { and depression } \\
\text { symptoms (not } \\
\text { significant for } \\
\text { PTSD) and morє } \\
\text { stress was } \\
\text { associated with } \\
\text { isolation and } \\
\text { restrictions }\end{array}$ \\
\hline $\begin{array}{l}\text { Müller et al., } \\
2018\end{array}$ & $\begin{array}{l}\text { Cross- } \\
\text { sectional } \\
\text { database } \\
\text { study }\end{array}$ & $\begin{array}{l}\mathrm{N}=620 ; \mathrm{N}=78 \\
\text { Asylum seekers } \\
\text { and migrants } \\
\text { with permanent } \\
\text { residency; } \\
\text { psychiatric } \\
\text { outpatient clinic }\end{array}$ & Turkey & Germany & $\begin{array}{l}\text { Medication, } \\
\text { Mental } \\
\text { Health } \\
\text { (Anxiety, } \\
\text { Depression, } \\
\text { PTSD) }\end{array}$ & $\begin{array}{l}\text { Asylum } \\
\text { application } \\
\text { status, language } \\
\text { proficiency }\end{array}$ & $\begin{array}{l}\text { MIGSTR10, } \\
\text { ICD-10 } \\
\text { Diagnosis }\end{array}$ & $\begin{array}{l}\text { Number of } \\
\text { psychiatric } \\
\text { diagnoses was } \\
\text { higher in Asylur } \\
\text { Seekers, } \\
\text { communication } \\
\text { problems, stress } \\
\text { related to } \\
\text { migration histor } \\
\text { shame feelings, } \\
\text { homesickness } \\
\text { and perceived } \\
\text { discrimination } \\
\text { occurred more } \\
\text { often in asylum } \\
\text { seekers; loss of } \\
\text { status and } \\
\text { feelings of guilt } \\
\text { were present in } \\
\text { both groups }\end{array}$ \\
\hline $\begin{array}{l}\text { Nickerson et } \\
\text { al., } 2015\end{array}$ & $\begin{array}{l}\text { Cross- } \\
\text { sectional } \\
\text { study }\end{array}$ & $\begin{array}{l}\mathrm{N}=134 \text { treatment } \\
\text { seeking refugees } \\
\text { and asylum } \\
\text { seekers }\end{array}$ & $\begin{array}{l}\text { Mostly from } \\
\text { Turkey } \\
(n=72), \text { Iran } \\
(n=16), \text { Sri } \\
\text { Lanka } \\
(n=11)\end{array}$ & Switzerland & $\begin{array}{l}\text { PTSD, } \\
\text { Depression, } \\
\text { Explosive } \\
\text { Disorder, } \\
\text { emotional } \\
\text { dysregulation }\end{array}$ & PMLD Checklist & $\begin{array}{l}\text { HTQ, HSCL, } \\
\text { PDS, DERS }\end{array}$ & $\begin{array}{l}\text { Trauma exposur } \\
\text { und PMLD were } \\
\text { associated with } \\
\text { PTSD, depressio } \\
\text { and explosive } \\
\text { anger; difficultie: } \\
\text { in emotion } \\
\text { regulation are } \\
\text { associated with } \\
\text { post-migration } \\
\text { living difficulties }\end{array}$ \\
\hline $\begin{array}{l}\text { Priebe et al., } \\
2013\end{array}$ & $\begin{array}{l}\text { Cross- } \\
\text { sectional } \\
\text { study }\end{array}$ & $\begin{array}{l}\mathrm{N}=854 \text { Refugees } \\
\text { in Western } \\
\text { countries } \\
\text { (n=3313 from } \\
\text { Balkan) } \\
\text { (only Refugees } \\
\text { included) }\end{array}$ & $\begin{array}{l}\text { Balkan } \\
\text { countries } \\
\text { (Bosnia- } \\
\text { Herzegovina, } \\
\text { Croatia, } \\
\text { Kosovo, } \\
\text { Macedonia, } \\
\text { Serbia }\end{array}$ & $\begin{array}{l}\text { UK, Italy, } \\
\text { Germany }\end{array}$ & $\begin{array}{l}\text { PTSD, } \\
\text { Depression, } \\
\text { Distress }\end{array}$ & $\begin{array}{l}\text { Employment, } \\
\text { Pre- and } \\
\text { Postwar } \\
\text { traumatic } \\
\text { experience, legal } \\
\text { status, feeling } \\
\text { accepted in host } \\
\text { country, Life } \\
\text { Stressor } \\
\text { Checklist- } \\
\text { Revised }\end{array}$ & $\begin{array}{l}\text { BSI, IES-R, } \\
\text { MINI }\end{array}$ & $\begin{array}{l}\text { Higher level of } \\
\text { psychiatric } \\
\text { symptoms was } \\
\text { associated with } \\
\text { postmigration } \\
\text { stressors and a } \\
\text { temporary legal } \\
\text { status; feeling } \\
\text { accepted in the } \\
\text { host country anc } \\
\text { being able to } \\
\text { communicate in } \\
\text { host language } \\
\text { were associated } \\
\text { with less severe } \\
\text { symptoms; } \\
\text { (employment we } \\
\text { associated with } \\
\text { lower symptom } \\
\text { level) }\end{array}$ \\
\hline $\begin{array}{l}\text { Schick et al., } \\
2016\end{array}$ & $\begin{array}{l}\text { Cross- } \\
\text { sectional } \\
\text { study }\end{array}$ & $\begin{array}{l}\mathrm{N}=104 \text { from two } \\
\text { outpatient clinics; } \\
\text { persons with a } \\
\text { legal status } \\
\text { (mean = } 10 \\
\text { years) }\end{array}$ & $\begin{array}{l}\text { Turkey, } \\
\text { Middle East, } \\
\text { Sri Lanka, } \\
\text { Former } \\
\text { Yugoslavia }\end{array}$ & Switzerland & $\begin{array}{l}\text { PTSD, } \\
\text { Anxiety, } \\
\text { Depression, } \\
\text { Health } \\
\text { related } \\
\text { quality of life }\end{array}$ & $\begin{array}{l}\text { Social } \\
\text { integration, } \\
\text { Language, } \\
\text { Employment, } \\
\text { Access to health } \\
\text { care, financial } \\
\text { situation, } \\
\text { accommodation, } \\
\text { social } \\
\text { participation, } \\
\text { discrimination, } \\
\text { criminality rate, } \\
\text { political } \\
\text { participation, } \\
\text { post-migration } \\
\text { education, } \\
\text { family } \\
\text { characteristics, } \\
\text { PMLD Checklist }\end{array}$ & $\begin{array}{l}\text { HTQ, PDS, } \\
\text { HSCL, SF-12 }\end{array}$ & $\begin{array}{l}\text { Social integratio } \\
\text { was poor, } \\
\text { participants } \\
\text { experienced } \\
\text { problems with } \\
\text { isolation, } \\
\text { employment anc } \\
\text { communication; } \\
\text { social integratio } \\
\text { correlated with } \\
\text { HRQL and } \\
\text { functional } \\
\text { impairment, } \\
\text { symptom severi1 } \\
\text { in depression an } \\
\text { anxiety; } \\
\text { symptoms and } \\
\text { PTSD and } \\
\text { depression } \\
\text { predicted } \\
\text { difficulties in } \\
\text { integration }\end{array}$ \\
\hline Spiller et al., & Cross- & $\mathrm{N}=134$ & Turkey, Iran, & Switzerland & PTSD, & PMLD Checklist & HTQ, PDS, & Correlations \\
\hline
\end{tabular}




\begin{tabular}{|c|c|c|c|c|c|c|c|c|}
\hline 2016 & $\begin{array}{l}\text { sectional } \\
\text { study }\end{array}$ & $\begin{array}{l}\text { traumatized } \\
\text { refugees and } \\
\text { asylum seekers }\end{array}$ & $\begin{array}{l}\text { Sri Lanka, } \\
\text { Iraq, Bosnia }\end{array}$ & & $\begin{array}{l}\text { somatization, } \\
\text { explosive } \\
\text { anger }\end{array}$ & & SCL-90 & $\begin{array}{l}\text { between PTSD, } \\
\text { anger, PMLD anı } \\
\text { trauma exposurє } \\
\text { no correlation } \\
\text { between PTSD } \\
\text { and length of } \\
\text { stay; PMLD werє } \\
\text { significant } \\
\text { predictors for } \\
\text { PTSD }\end{array}$ \\
\hline $\begin{array}{l}\text { Steel et al., } \\
2016\end{array}$ & $\begin{array}{l}\text { Cross- } \\
\text { sectional } \\
\text { study }\end{array}$ & $\begin{array}{l}\mathrm{N}=420 \text { refugees } \\
\text { and immigrants }\end{array}$ & $\begin{array}{l}\text { African } \\
\text { countries } \\
\text { (mainly } \\
\text { Somalia, } \\
\text { Ethiopia and } \\
\text { Eritrea) }\end{array}$ & Sweden & $\begin{array}{l}\text { PTSD, } \\
\text { Depression, } \\
\text { Anxiety }\end{array}$ & $\begin{array}{l}\text { PMDL Checklist, } \\
\text { Cultural Lifestyle } \\
\text { Questionnaire }\end{array}$ & HTQ, HSCL & $\begin{array}{l}\text { Postmigration } \\
\text { stress was a } \\
\text { significant } \\
\text { predictor for } \\
\text { depression and } \\
\text { PTSD but not fo } \\
\text { anxiety }\end{array}$ \\
\hline $\begin{array}{l}\text { Teodorescu } \\
\text { et al., } 2012\end{array}$ & $\begin{array}{l}\text { Cross- } \\
\text { sectional } \\
\text { study }\end{array}$ & $\begin{array}{l}\mathrm{N}=61 \text { refugee } \\
\text { outpatients }\end{array}$ & $\begin{array}{l}21 \text { countries, } \\
\text { majority } \\
\text { from Eastern } \\
\text { Europe }\end{array}$ & Norway & $\begin{array}{l}\text { PTSD, } \\
\text { Distress, } \\
\text { Depression }\end{array}$ & $\begin{array}{l}\text { Employment, } \\
\text { Social Network, } \\
\text { Social } \\
\text { integration in the } \\
\text { Norwegian } \\
\text { Culture and in } \\
\text { the immigrant } \\
\text { ethnic culture, } \\
\text { proficiency of } \\
\text { Norwegian } \\
\text { language }\end{array}$ & $\begin{array}{l}\text { SCID PTSD, } \\
\text { MINI, SIDES, } \\
\text { HSCL, IES-R, } \\
\text { LEC }\end{array}$ & $\begin{array}{l}\text { Weak social } \\
\text { network, weak } \\
\text { social integratio } \\
\text { in the Norwegiar } \\
\text { community and } \\
\text { into the ethnic } \\
\text { community, } \\
\text { unemployment } \\
\text { was associated } \\
\text { with psychiatric } \\
\text { morbidity and } \\
\text { higher levels of } \\
\text { symptom severit }\end{array}$ \\
\hline $\begin{array}{l}\text { Teodorescu } \\
\text { et al., } 2012\end{array}$ & $\begin{array}{l}\text { Cross- } \\
\text { sectional } \\
\text { study }\end{array}$ & $\begin{array}{l}\mathrm{N}=55 \\
\text { outpatients with } \\
\text { a refugee } \\
\text { background }\end{array}$ & Not stated & Norway & $\begin{array}{l}\text { PTSD, mental } \\
\text { disorders, } \\
\text { depression, } \\
\text { health related } \\
\text { quality of life }\end{array}$ & $\begin{array}{l}\text { Social } \\
\text { integration } \\
\text { social network, } \\
\text { employment }\end{array}$ & $\begin{array}{l}\text { LEC, CAPS, } \\
\text { SCID-PTSD } \\
\text { Structural, } \\
\text { MINI, IES-R, } \\
\text { HSCL, PTGI- } \\
\text { SF, WHOQOL }\end{array}$ & $\begin{array}{l}\text { Posttraumatic } \\
\text { stress and } \\
\text { depressive } \\
\text { symptoms were } \\
\text { significantly anc } \\
\text { positively } \\
\text { correlated with } \\
\text { post-migration } \\
\text { stress variables; } \\
\text { Depression was } \\
\text { associated with } \\
\text { psychological } \\
\text { health, social } \\
\text { relationships an } \\
\text { environment; } \\
\text { Unemployment } \\
\text { was only } \\
\text { associated with } \\
\text { the environment } \\
\text { scale }\end{array}$ \\
\hline $\begin{array}{l}\text { Winkler et al, } \\
2019\end{array}$ & $\begin{array}{l}\text { Cross- } \\
\text { sectional } \\
\text { study }\end{array}$ & $\begin{array}{l}\mathrm{N}=650 \text { refugees } \\
\text { from communal } \\
\text { accommodations } \\
\text { in Berlin }\end{array}$ & $\begin{array}{l}47 \text { different } \\
\text { ethnic } \\
\text { minorities }\end{array}$ & Germany & $\begin{array}{l}\text { PTSD, } \\
\text { Depression, } \\
\text { Anxiety }\end{array}$ & $\begin{array}{l}\text { Questions about } \\
\text { residence status } \\
\text { and the asylum } \\
\text { procedure }\end{array}$ & HSCL, PDS & $\begin{array}{l}\text { Significant } \\
\text { correlations } \\
\text { between } \\
\text { residence status } \\
\text { and the severity } \\
\text { of psychiatric } \\
\text { disorders but no } \\
\text { between } \\
\text { residence status } \\
\text { and the existenc } \\
\text { of psychiatric } \\
\text { disorders }\end{array}$ \\
\hline
\end{tabular}

\section{Figures}




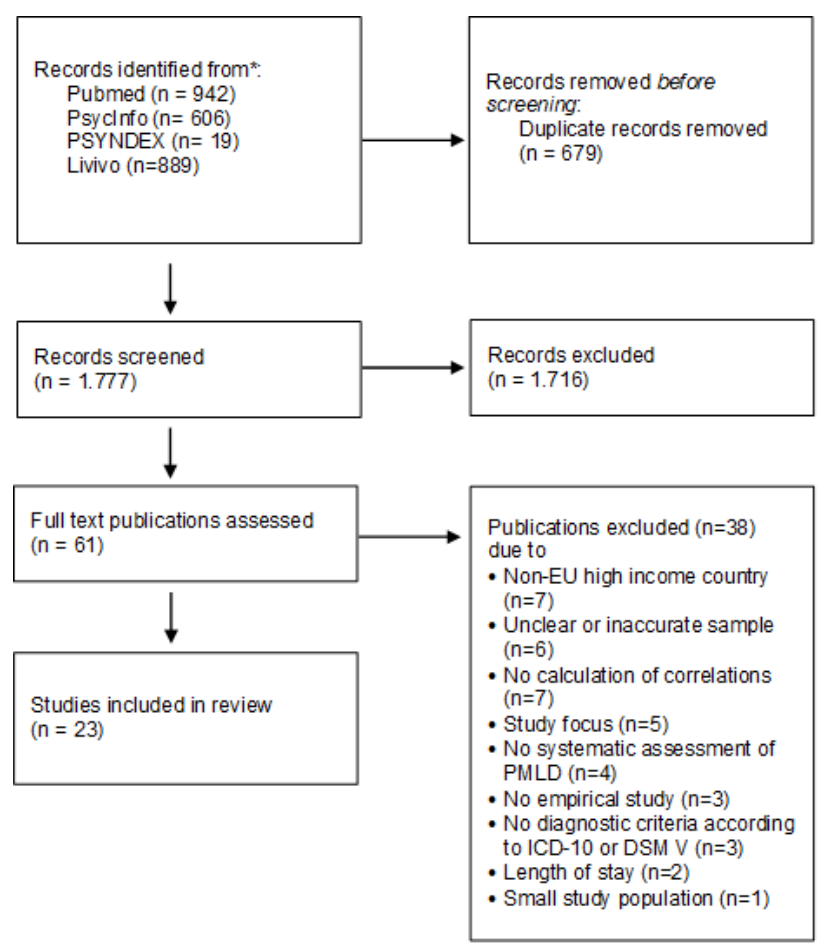

Figure 1

Prisma flow diagram showing the selection of studies 